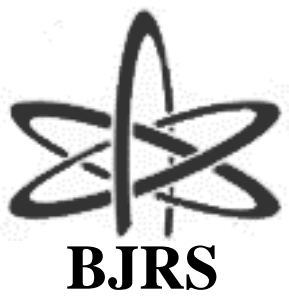

\author{
BRAZILIAN JOURNAL \\ $\mathrm{OF}$ \\ RADIATION SCIENCES \\ $\mathrm{XX}(\mathrm{XXXX}) \mathrm{XX}-\mathrm{XX}$
}

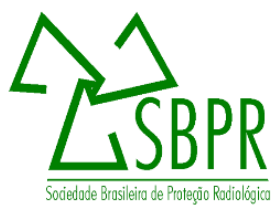

\title{
Evaluation of mercury levels in hair of children resident in artisanal gold mining area in the city of Chapada de
} Natividade - Tocantins

\author{
Mendes $^{a}$ S.U.R., Vasconcellos ${ }^{b}$ M.B.A., Catharino ${ }^{b}$ M.G.M., Quinaglia ${ }^{c}$ G.A., Held \\ B. \\ ${ }^{a}$ Universidade Federal do Tocantins, Coordenação de Medicina, CEP 77001-090, Palmas, Tocantins, Brazil \\ ${ }^{b}$ Instituto de Pesquisas Energéticas e Nucleares, Centro do Reator de Pesquisa, CEP 05508-000, São Paulo, SP,
}

Brazil

${ }^{c}$ CETESB, Setor De Análises Toxicológicas, CEP05459-900, São Paulo, SP, Brazil

mbvascon@ipen.br

\begin{abstract}
The objective of the work is to evaluate the mercury exposure of children living in an artisanal gold mining area and in a control area, without mining. A cross-sectional study was conducted with children living in the municipalities of Chapada de Natividade and Porto Nacional, in the State of Tocantins, where hair samples were collected for laboratorial analysis of mercury concentrations, comparing between municipalities, gender, monthly fish consumption, profession of parents and the presence of amalgam in dental restorations. The hair samples were analyzed by the methods of neutron activation analysis and also by means of the DMA (Direct Mercury Analyzer) equipment. There was no evidence of mercury-related diseases in the studied children. The mean concentration of mercury in children in Chapada de Natividade was significantly higher than in Porto Nacional. Children exposed to artisanal gold mining areas have higher concentrations of mercury than children living in non-artisanal gold mining areas. There was no significant relationship between mercury concentrations and gender, monthly fish consumption, parental profession and amalgam presence in dental restorations. The results suggest that the children living in an area exposed to mining experience greater environmental exposure to mercury, regardless of their eating habits.
\end{abstract}

Keywords: mercury, hair, children, artisanal gold mining, Tocantins

ISSN: 2319-0612

Accepted: 2018-11-02 


\section{INTRODUCTION}

Mercury $(\mathrm{Hg})$ can be found naturally in the environment or as a consequence of human activities. Elevated levels of mercury in humans, mainly as methylmercury $(\mathrm{MeHg})$ are related to the consumption of fish and also other seafood, such as shrimp, crab, octopus and others [1].

$\mathrm{MeHg}$ is one of the main chemical forms of mercury and it is a well-known neurotoxin. $\mathrm{MeHg}$ in the human body presents a relatively long half life, of about 70 to 80 days [1].

Historic episodes of mercury intoxication of great population impact occurred in Japan, in the 1960's and in Iraq, in the 1970's, and had, as consequences, sensorial and movement alterations in the exposed people and also resulted in many deaths [2]. In Japan, these effects became known as Minamata disease.

The adverse effects of the acute exposition to MeHg during pregnancy have been documented since the episodes of Japan in the city of Minamata and include neurological symptoms and delays in the development of children [3].

In addition, hair samples have been widely used in several studies that evaluate levels of environmental exposure to mercury via food intake in humans [4].

The Ministry of Environment of Japan considers that the mercury concentration in hair is a useful biological monitor, frequently utilized to study $\mathrm{MeHg}$ exposure, because it reflects the concentration in blood in the occasion in which the hair was formed [5].

Mercury concentration in hair is generally about 250-300 higher than the concentration in blood. Also, since hair grows at a rate of about $1 \mathrm{~cm}$ per month, it is possible to evaluate the past exposure. The exposure of children to mercury, as regard localization, can be divided in three categories: at home, at school and also at locations close to industries that are not adequately remediated and close to medical installations [6]. In all these locations, the primary exposure to elemental $\mathrm{Hg}$ is inhalation. A great part of the mercury utilized in the process of extraction and amalgamation of gold present in ores, in the artisanal gold mining activities, is thrown in rivers, and consequently deposited in the benthic sediments. By means of a series of chemical reactions, inorganic mercury is transformed in methylmercury, which can eventually become highly concentrated in carnivorous fish species, at the top of the aquatic food chain [7]. 
In one of the many studies conducted in the Amazonic region, it was shown that the human exposure to mercury by means of ingestion of fish caught in the region, constitute a potential risk for the occurrence of Minamata disease, which should recommend the maintenance of a program of epidemiological surveillance [7]. As a consequence, the consumption of fish that come from regions close to artisanal gold mining activities can give rise to a risk of exposure of adults and children to mercury in the Amazon.

In the gold mining sites, where mercury is used for amalgamation of the precious metal, individuals may present some neurobehavioral problems, arising from chronic exposure to mercury. The effects of this kind of exposure are generally subclinical and can be detected only by means of very specific tests [4].

The efforts to reduce the exposure to $\mathrm{MeHg}$ can bring high social and environmental benefits, since they can prevent the complications and longtime consequences of the deficits in neurological development of children, since they are particularly vulnerable to the neurotoxic effects of metals [8].

So, it is of great relevance to determine the mercury concentrations in the hair of children living in a region of exposure to mercury due to artisanal gold mining activities, in the municipality of Chapada de Natividade, in the State of Tocantins - Brazil.

\section{MATERIALS AND METHODS}

\subsection{Study group and sample collection}

A cross-sectional study was made, after approval of the project by the Ethics Committee in Research (CEP) of the Brazil Platform (CAAE 341122414.7.0000.5516), with children resident in two municipalities of the State of Tocantins. In the first one, Chapada de Natividade, artisanal gold mining (garimpo) activities are conducted, and in the second one, Porto Nacional, there are no such activities.

The children were selected from the cadaster of the public service of basic attention (SUS), in their municipalities, and were invited to participate during visits at their homes. Their parents or 
other responsible adults were informed about the purposes and methodology of the study and were asked to give their formal authorization, by signing a Consent Term. Before collection of the hair samples, the clinical, sociodemographic and nutritional habits data of the children were collected and registered in a proper form, by the family and the community physician responsible for the study.

The children included in the study had the following characteristics: age range from 5 to 6 years; no history of working in the artisanal gold mining; no infectious diseases in the scalp; both genders; no use of chemical products in the hair (such as dyes or smoothing products); presence of enough hair for sampling; parental consent.

About $500 \mathrm{mg}$ of the children's hair samples were collected in the occipital region of the head, close to the scalp, using titanium scissors, previously cleaned with ethanol. In the case of children with long hair, only the $10 \mathrm{~cm}$ closest to the scalp were utilized.

\subsection{Sample Preparation}

The sample preparation was carried out according to the protocol of the International Atomic Energy Agency, which includes cutting hair samples in small fragments, smaller than $2 \mathrm{~mm}$ and several washings with acetone-water [9]. After drying, at room temperature, the samples were stored in polyethylene flasks, previously washed with $10 \% \mathrm{HNO}_{3}$, being then ready for analysis.

At first it was tried to analyze the samples by neutron activation analysis, by irradiating at the IEA-R1 nuclear research reactor of IPEN-CNEN/SP, but due to the low concentrations of mercury in hair of the children, most of the results were below the detection limit.

Due to this fact, the mercury analysis in the hair samples were carried out at the Department of Toxicological Analysis of CETESB, the Company for Environmental Control of the State of São Paulo, by utilizing the DMA 80 equipment (Direct Mercury Analyzer), whose detection limit is of 0.01 nanograms of total mercury.

The analyses were performed according to USEPA - SW86, Method 7473 "Mercury in solids and solutions by thermal decomposition, amalgamation and atomic absorption spectrophotometry" and to the Application Book of Milestone Company [10]. 
For quality control, the Human Hair - IAEA 086 Reference Material, from the International Atomic Energy Agency, was analyzed, together with the samples. This material has a recommended value for total Mercury of $0.573 \mu \mathrm{g} \mathrm{g}^{-1}$, with a confidence interval at $95 \%$ of 0.534 to $0.612 \mu \mathrm{g} \mathrm{g}^{-1}$.

\section{RESULTS AND DISCUSSION}

The mean result, relative standard deviation and relative error for the reference material IAEA-086 are, respectively, $0.608 \pm 0,017 \mu \mathrm{g} \mathrm{g}-1,2.8 \%$ and $6.1 \%$ and can be considered as satisfactory, as to the relative standard deviation and relative error obtained.

Table 1 presents the results obtained for $\mathrm{Hg}$ concentrations in hair of the children resident in the municipality of Chapada de Natividade, where there are artisanal gold mining activities.

Table 1: Individual results of $\mathrm{Hg}$ concentrations in hair samples of children from the municipality of Chapada de Natividade - TO

\begin{tabular}{|c|c|c|c|}
\hline Sample Code & Hg concentration $\left(\mu \mathrm{g} \mathrm{g}^{-1}\right)$ & Gender & Fish consumption \\
\hline $\mathrm{C} 1$ & $0.205 \pm 0.0079$ & $\mathrm{~F}$ & $1 \mathrm{x} / \mathrm{month}$ \\
\hline $\mathrm{C} 2$ & $0.356 \pm 0.0020$ & $\mathrm{~F}$ & $4 \mathrm{x} / \mathrm{month}$ \\
\hline $\mathrm{C} 3$ & $0.108 \pm 0.0029$ & $\mathrm{~F}$ & $16 x /$ month \\
\hline $\mathrm{C} 4$ & $0.060 \pm 0.0046$ & M & $8 \mathrm{x} / \mathrm{month}$ \\
\hline C5 & $0.690 \pm 0.0028$ & $\mathrm{~F}$ & Rarely \\
\hline C6 & $0.109 \pm 0.0024$ & M & $12 \mathrm{x} /$ month \\
\hline $\mathrm{C} 7$ & $0.520 \pm 0.0493$ & $\mathrm{~F}$ & $4 \mathrm{x} /$ month \\
\hline $\mathrm{C} 8$ & $0.111 \pm 0.0024$ & $\mathrm{~F}$ & $3 x /$ month \\
\hline $\mathrm{C} 9$ & $0.436 \pm 0.0077$ & M & $3 x /$ month \\
\hline $\mathrm{C} 10$ & $0.100 \pm 0.0020$ & M & $2 \mathrm{x} / \mathrm{month}$ \\
\hline $\mathrm{C} 11$ & $0.313 \pm 0.0001$ & M & $2 \mathrm{x} / \mathrm{month}$ \\
\hline $\mathrm{C} 12$ & $0.130 \pm 0.0039$ & $\mathrm{~F}$ & $2 \mathrm{x} / \mathrm{month}$ \\
\hline $\mathrm{C} 13$ & $0.103 \pm 0.0019$ & M & $12 \mathrm{x} /$ month \\
\hline $\mathrm{C} 14$ & $0.076 \pm 0.0042$ & $\mathrm{~F}$ & $1 \mathrm{x} / \mathrm{month}$ \\
\hline
\end{tabular}




\begin{tabular}{llll} 
C15 & $0.098 \pm 0.0035$ & F & $8 \mathrm{x} /$ month \\
C16 & $0.104 \pm 0.0024$ & F & $1 \mathrm{x} / \mathrm{month}$ \\
$\mathrm{C} 17$ & $0.243 \pm 0.0172$ & $\mathrm{~F}$ & $8 \mathrm{x} / \mathrm{month}$ \\
$\mathrm{C} 18$ & $0.457 \pm 0.0013$ & $\mathrm{~F}$ & $8 \mathrm{x} / \mathrm{month}$ \\
$\mathrm{C} 19$ & $0.133 \pm 0.0015$ & $\mathrm{~F}$ & $2 \mathrm{x} / \mathrm{month}$ \\
$\mathrm{C} 20$ & $0.921 \pm 0.0484$ & $\mathrm{~F}$ & $4 \mathrm{x} / \mathrm{month}$ \\
$\mathrm{C} 21$ & $0.237 \pm 0.0074$ & $\mathrm{~F}$ & $8 \mathrm{x} / \mathrm{month}$ \\
$\mathrm{C} 22$ & $0.040 \pm 0.0024$ & $\mathrm{~F}$ & $4 \mathrm{x} / \mathrm{month}$ \\
$\mathrm{C} 23$ & $0.117 \pm 0.0015$ & $\mathrm{~F}$ & $2 \mathrm{x} / \mathrm{semester}$ \\
$\mathrm{C} 24$ & $0.230 \pm 0.0011$ & $\mathrm{~F}$ & $1 \mathrm{x} / \mathrm{month}$ \\
$\mathrm{C} 25$ & $0.195 \pm 0.0044$ & $\mathrm{~F}$ & $2 \mathrm{x} / \mathrm{month}$ \\
$\mathrm{C} 26$ & $0.649 \pm 0.0007$ & $\mathrm{~F}$ & $1 \mathrm{x} / \mathrm{month}$ \\
$\mathrm{C} 27$ & $0.369 \pm 0.0006$ & $\mathrm{~F}$ & $2 \mathrm{x} / \mathrm{month}$ \\
$\mathrm{C} 28$ & $0.171 \pm 0.0018$ & $\mathrm{~F}$ & $2 \mathrm{x} / \mathrm{month}$ \\
$\mathrm{C} 29$ & $0.125 \pm 0.0005$ & $\mathrm{~F}$ & $1 \mathrm{x} / \mathrm{month}$ \\
$\mathrm{C} 30$ & $0.070 \pm 0.0002$ & $\mathrm{M}$ & $1 \mathrm{x} / \mathrm{month}$ \\
\hline
\end{tabular}

The $\mathrm{Hg}$ concentration range for the children of Chapada de Natividade was from 0.038 to $0.921 \mu \mathrm{g} \mathrm{g}^{-1}$, and the arithmetic mean, geometric mean and median were, respectively, $0.249,0.183$ and $0.152 \mu \mathrm{g} \mathrm{g}^{-1}$. None of the children presented $\mathrm{Hg}$ values above $1.0 \mu \mathrm{g} \mathrm{g}^{-1}$ which is the limit set by the National Research Council of the USA [11].

In Table 2 are presented the results obtained for $\mathrm{Hg}$ concentrations in hair of the children resident in the municipality of Porto Nacional, where there are no artisanal gold mining activities.

Table 2: Individual results of $\mathrm{Hg}$ concentration in hair sample of children living in the municipality of Porto Nacional - TO.

\begin{tabular}{cccc}
\hline Sample Code & Concentration of $\mathbf{~ H g}\left(\boldsymbol{\mu g ~ \mathbf { g } ^ { - 1 } )}\right.$ & Gender & Fish Consumption \\
\hline P1 & $0.167 \pm 0.0032$ & $\mathrm{~F}$ & $4 \mathrm{x} /$ month \\
P2 & $0.079 \pm 0.0021$ & $\mathrm{M}$ & $1 \mathrm{x} /$ month \\
\hline
\end{tabular}




\begin{tabular}{|c|c|c|c|}
\hline P3 & $0.083 \pm 0.0059$ & $\mathrm{~F}$ & $2 \mathrm{x} / \mathrm{month}$ \\
\hline $\mathrm{P} 4$ & $0.175 \pm 0.0047$ & $\mathrm{~F}$ & Rarely \\
\hline P5 & $0.076 \pm 0.0011$ & $\mathrm{~F}$ & $12 \mathrm{x} /$ month \\
\hline P6 & $0.222 \pm 0.0113$ & $\mathrm{M}$ & $1 \mathrm{x} / \mathrm{month}$ \\
\hline $\mathrm{P} 7$ & $0.172 \pm 0.0029$ & $\mathrm{~F}$ & $8 \mathrm{x} /$ month \\
\hline P8 & $0.132 \pm 0.0042$ & $\mathrm{~F}$ & $4 \mathrm{x} /$ month \\
\hline P9 & $0.192 \pm 0.0011$ & $\mathrm{~F}$ & $1 \mathrm{x} /$ month \\
\hline P10 & $0.195 \pm 0.0019$ & $\mathrm{~F}$ & $1 \mathrm{x} /$ month \\
\hline P11 & $0.098 \pm 0.0002$ & $\mathrm{~F}$ & Rarely \\
\hline $\mathrm{P} 12$ & $0.375 \pm 0.0000$ & $\mathrm{~F}$ & $4 \mathrm{x} /$ month \\
\hline $\mathrm{P} 13$ & $0.177 \pm 0.0012$ & $\mathrm{~F}$ & $4 \mathrm{x} /$ month \\
\hline P14 & $0.141 \pm 0.0026$ & $\mathrm{~F}$ & $12 \mathrm{x} /$ month \\
\hline P15 & $0.078 \pm 0.0022$ & $\mathrm{~F}$ & $8 \mathrm{x} / \mathrm{month}$ \\
\hline
\end{tabular}

The $\mathrm{Hg}$ concentration range for the children of Porto Nacional was from 0.076 to $0.375 \mu \mathrm{g} \mathrm{g}^{-1}$, and the arithmetic mean, geometric mean and median were, respectively, $0.157,0.142$ and $0.168 \mu \mathrm{g} \mathrm{g}^{-1}$. Also in this case, none of the children presented $\mathrm{Hg}$ values above $1.0 \mu \mathrm{g} \mathrm{g}^{-1}$ which is the limit set by the National Research Council of the USA [11].

In the NAHNES (National Health and Nutrition Examination Survey) study [12], carried out in the United States, with children from 1 to 5 years and women of child-bearing age, the authors obtained a geometric mean for total mercury of $0.12 \mu \mathrm{g} \mathrm{g}^{-1}$ for the children. The authors consider that the study constitutes a reference data base for the American children, as regards $\mathrm{Hg}$ concentration in this age range. This value is similar to the one obtained, of $0.142 \mu \mathrm{g} \mathrm{g}^{-1}$, for the non-exposed children of Porto Nacional.

In the European DEMOCOPHES project, with the participation of 17 countries, the geometric mean found, for children in the age range from 6 to 11 years old, was of $0.14 \mu \mathrm{g} \mathrm{g}^{-1}$. This mean concentration was also similar to the one obtained for the children of Porto Nacional, which was of $0.142 \mu \mathrm{g} \mathrm{g}^{-1} \mathrm{Hg}$ (geometric mean). On the other hand, in the DEMOCOPHES project, it has to be pointed out that significant differences have been found between the countries, with a factor of 50 
between the lowest (Hungary) and the highest (Portugal). Fish consumption and social status were found to be important and independent factors, determinant of mercury levels in hair [13].

A study carried out in a traditional riverine population of the Tapajós river, in the Amazonic region of Brazil, with 32 mothers and their 51 children, revealed very high concentrations of total $\mathrm{Hg}$ and $\mathrm{MeHg}$. The ranges of total $\mathrm{Hg}$ and $\mathrm{MeHg}$ concentrations in hair were, respectively, of 1.0 to 51.0 and 0.5 to $41.4 \mu \mathrm{g} \mathrm{g}^{-1}$, with mean values of 12.4 and $10.2 \mu \mathrm{g} \mathrm{g}^{-1}$. The relative mean value of $\mathrm{MeHg}$ was $80 \%$. This population reported high fish consumption, from 4 to 14 times a week [14].

Due to the fact that children are more vulnerable to mercury toxicity, another study was made in the Amazonic region of Brazil, in the state of Rondônia, with children aged from 3 to 9 years old, in two localities: Demarcação (DA) and Gleba do Rio Preto (GRP). Besides Hg, selenium was also determined in the hair of the children, since it has been considered that it can delay mercury intoxication symptoms by forming an inert complex with $\mathrm{Hg}$. High mean mercury levels were found in the children from both localities: $3.6 \mu \mathrm{g} \mathrm{g}^{-1}$ for DA and $6.2 \mu \mathrm{g} \mathrm{g}^{-1}$ for GRP [15].

\subsection{Statistical Treatment}

The results obtained for mercury in the hair of the children of the two municipalities were evaluated by means of statistical tests, considering $\mathrm{p}<0.05$ as the index of rejection of the null hypothesis by the Student t-test.

Figures 1 and 2 present, respectively, the mean concentrations of mercury in the hair of children resident in the two municipalities studied and the concentrations of mercury related to fish consumption. 
Figure 1: Mean concentrations $\left(\mu \mathrm{g}^{-1}\right)$ in hair of children in the two municipalities studied

$$
p=0.02(p<0.05)
$$

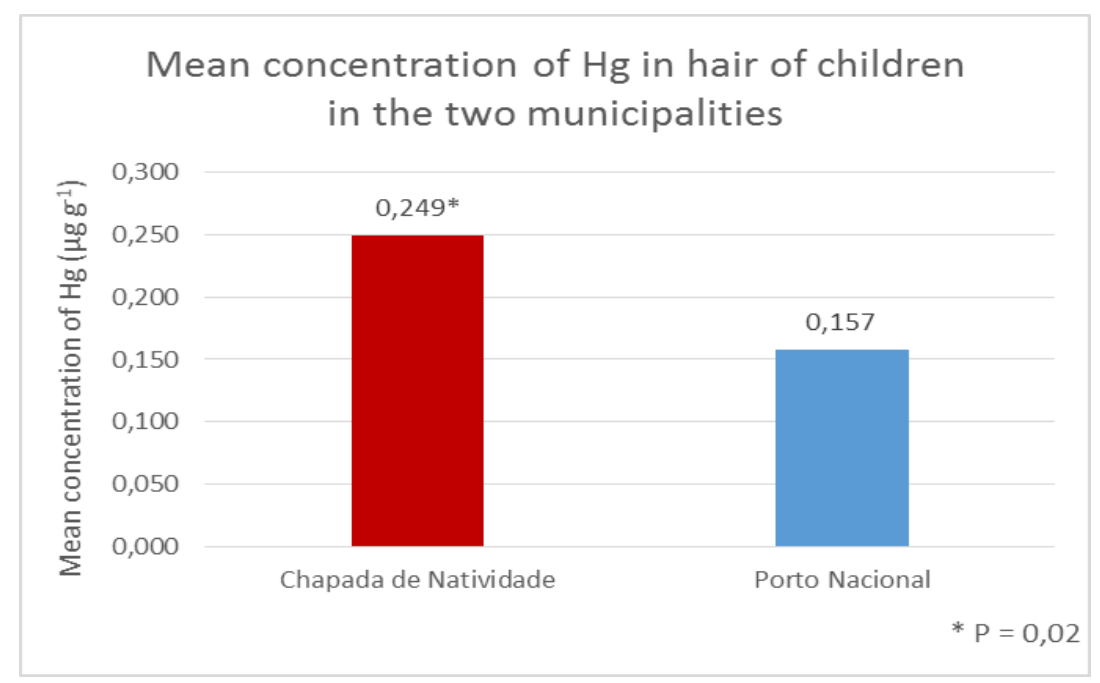

Figure 2: Mean concentration of $\mathrm{Hg}$ vs monthly fish consumption. $p=0.30(p>0.05)$.

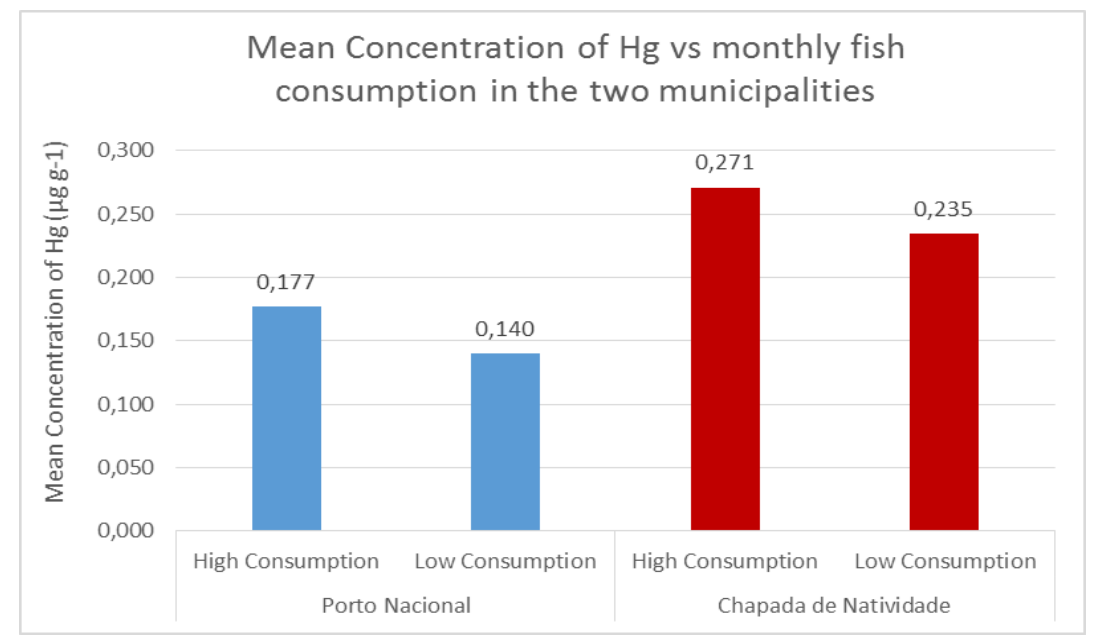

According to Figure 1, it can be observed that the mean mercury concentration in the hair of the children of Chapada de Natividade was significantly higher $(p<0.05)$ than the concentrations of the children of Porto Nacional. It can be seen in Figure 2, that the children who consume fish frequently (equal or more than 4 times a month) present $\mathrm{Hg}$ concentrations higher, with mean concentration of 
$0.236 \mu \mathrm{g} \mathrm{g}^{-1} \mathrm{Hg}$, than the ones who do not consume or have a lower consumption of fish (less than 4 times a month), who present a mean concentration of $0.206 \mu \mathrm{g} \mathrm{g}^{-1}$. On the other hand, it was observed that there was no statistically significant difference as regards high vs low fish consumption, since $\mathrm{p}=0.30(\mathrm{p}>0.05)$.

A similar statistical treatment carried out for the results of both municipalities has shown that the mean $\mathrm{Hg}$ concentration for the feminine gender was of $0.232 \mu \mathrm{g} \mathrm{g}^{-1}$ and for the masculine gender it was of $0.166 \mu \mathrm{g} \mathrm{g}^{-1}$. The mean concentration of $\mathrm{Hg}$ in relation to the presence of dental amalgam, which contains mercury, was $0.250 \mu \mathrm{g} \mathrm{g}^{-1}$ for the children that had amalgam fillings and of $0.210 \mu \mathrm{g} \mathrm{g}^{-1}$ for those without amalgam fillings. Both relations, (gender X Hg) and (amalgam X Hg), did not present statistically significant differences, with values of $\mathrm{p}$ equal to 0.12 and 0.28 $(\mathrm{p}>0.05)$, respectively.

During the hair samples collection, in the municipalities of Chapada de Natividade and Porto Nacional, no cases of children's work in the artisanal gold mining were detected. On the other hand, some families lived in houses that were built on the same land where the artisanal gold mining was carried out, mainly when the parents or other responsible adults worked as gold miners. There were some reports also that the children played close to the places where the gold - mercury amalgam was heated to eliminate mercury, with the consequence of the children inhaling mercury. Besides the risks of environmental exposure inside the residence, the families were also exposed to the mercury residues disposed in the surrounding soil, where domestic animals and also animals raised for feeding, such as chicken and swines are present. It was observed that the children whose parents or responsible adults were workers in artisanal gold mining activities had higher mercury concentrations $\left(0.294 \mu \mathrm{g} \mathrm{g}^{-1}\right)$ than those whose parents worked in other professions $\left(0.205 \mu \mathrm{g} \mathrm{g}^{-1}\right)$, but without statistical significance, which suggests that the environmental exposure to mercury can be extended to houses in which there are no gold extraction activities.

Montuori et al [16] studied, also in Spain, the $\mathrm{Hg}$ speciation in the hair of preschool children, of age 4, living in two areas, both exposed to different sources of Hg: a point source in Ribera d Ebre (RE) and a diffuse source on the island of Menorca (MC). The total $\mathrm{Hg}$ and $\mathrm{MeHg}$ median values found for RE were much higher than the values found for MC. Children who consumed fish more than three times a week had higher methylmercury ( $\mathrm{MeHg}$ ) concentrations than those who consumed less than once a week. On the other hand, the differences in MeHg between the children 
from RE and MC remained statistically significant even after adjustment for fish consumption and other variables, which suggests that populations with similar fish consumption may receive different levels of exposure to mercury due to their proximity to mercury-related industrial activities.

\section{CONCLUSIONS}

This study demonstrated that the mean concentration of $\mathrm{Hg}$ in hair samples of children living in an area exposed to artisanal gold mining activities, in the municipality of Chapada de Natividade was significantly higher than in a non-exposed area, in the municipality of Porto Nacional.

There was no statistically significant difference related to gender, monthly fish consumption of the parents, accidents with mercury thermometers or presence of amalgam fillings in teeth in areas close to industrial and mining activities.

The results of the present study thus suggest that children living in a region exposed to artisanal gold mining are environmentally exposed to mercury, regardless of their eating habits or gender.

\section{ACKNOWLEDGMENTS}

The authors would like to thank CETESB for the analysis of mercury by the DMA method.

\section{REFERENCES}

[1] LEE, C. C., CHANG, J. W.; HUANG, H. Y., CHEN, H. L. Factors influencing blood mercury levels of inhabitants living near fishing areas. Science of the Total Environment, v. 424, p.316-321, 2012.

[2] KHOURY, E. D. T.; SOUZA, G. S.; SILVEIRA, L. C. L.; COSTA, C. A.; ARAÚJO, A. A.; PINHEIRO, M. C. N. Manifestações neurológicas em ribeirinhos de áreas expostas ao mercúrio na Amazônia brasileira. Cadernos de Saúde Pública, n. 29, v.11, p.2307-2318, 2013. 
[3] BOUCHER, O.; JACOBSON, S. W.; PluSQUElleC, P.; DEWAIllY, E.; AYOTTE, P.; FORGET-DUBOIS, N.; JACOBSON, J. L.; MUCKLE, G. Prenatal methylmercury, postnatal lead exposure, and evidence of attention deficit/hyperactivity disorder among Inuit Children in Arctic Québec. Environmental Health Perspectives, n. 120, v. 10, p.1456-146, 2012.

[4] SILVA T. M. Biomonitoramento da exposição humana ao mercúrio ( $\mathrm{Hg}$ ) na população da área de influência do aproveitamento elétrico de Jirau, Bacia do Rio madeira, Estado de Rondônia. Trabalho de conclusão de curso de Bacharelado de gestão ambiental, Planaltina, DF, Faculdade UnB Planaltina, Universidade de Brasília, 2012.

[5] JAPÃO, Ministério do Meio Ambiente, Manual de Análises de Mercúrio, Tradução Terezinha M. Cid de Souza, 2004.

[6] LEE, R.; MIDDLETON, D.; CALDWELL, K.; DEARWENT, S.; JONES, S.; LEWIS, B.; MONTEILH, C.; MORTENSEN, M. E.; NICKLE, R.; ORLOFF, K.; REGER, M.; RISHER, J.; ROGERS, H. S.; WATTERS, M. A review of events that expose children to elementary mercury in the United States. Environmental Health Perspectives, v. 117, p.871-878, 2009.

[7] PINHEIRO, M. C. N.; GUIMARÃES, G. A.; NAKANISHI, J.; OIKAWA, T.; VIEIRA, J. L.; QUARESMA, M.; CARDOSO, B.; AMORAS, W. Avaliação da contaminação mercurial mediante análise do teor de $\mathrm{Hg}$ total em amostras de cabelo em comunidades ribeirinhas do Tapajós, Pará, Brasil. Revista da Sociedade Brasileira de Medicina Tropical, n. 33, v. 2, p.181-184, 2000.

[8] PICHERY, C.; BELlangER, M.; ZMIROU-NAVIER, D.; FRÉRY, N.; CORDIER, S.; ROUE-LEGALI, A.; HARTEMANN, P.; GRANDJEAN, P. Economic evaluation of health consequences of prenatal methylmercury exposure in France. Environmental Health, n. 11, v. 53, p.1-10, 2012.

[9] IAEA-International Atomic Energy Agency. Reference methods for marine pollution studies. IAEA-MEL-46, Vienna: IAEA, 1987.

[10] USEPA-SW86, Method 7473. Mercury in solids and solutions by thermal decomposition, amalgamation and atomic absorption spectrophotometry, 2007.

[11] NRC-National Research Council. Committee on the toxicological effects of methylmercury. National Academy Press, Washington, DC (2000). 
[12] MCDOWELl, M. A.; DILlON, C. F.; OSTERLOH, J.; BOLGER, P. M.; PELLIZZARI, E.; FERNANDO, R.; DE OCA, R. M.; SCHOBER, S. E.; SINKS, T.; JONES, R. L.; MAHAFFEY, K. R. Hair mercury levels in US children and women of childbearing age: reference range data from NAHNES 1999-2000. Environmental Health Perspectives, n. 112, v. 11, p.1165-1171, 2004.

[13] CASTAÑO, A.; CUTANDA, F.; ESTEBAN, M.; PÄRT, P.; NAVARRO, C.; GÓMEZ, S.; ROSADO, M.; LÓPEZ, A.; LÓPEZ, E.; EXLEY, K.; SCHINDLER, B. K.; GOVARTS, E.; CASTELEYN, L.; KOLOSSA-GEHRING, M.; FIDDICKE, U.; KOCH, H.; ANGERER, J.; HOND, E. D.; SCHOETERS, G.; SEPAI, O.; HORVAT, M.; KNUDSEN, L.E.; AERTS, D.; JOAS, A.; BIOT, P.; JOAS, R.; JIMÉNEZ-GUERRERO, J.A.; DIAZ, G.; PIRARD, C.; KATSONOURI, A.; CERNA, M.; GUTLEB, A. C.; LIGOCKA, D.; REIS, F. M.; BERGLUND, M.; LUPSA, I. R.; HALZLOVÁ, K.; CHARLIER, C.; CULLEN, E.; HADJIPANAYIS, A.; KRSKOVÁ, A.; JUNSEN, J. F.; NIELSEN, J. K.; SCHWEDLER, G.; WILHELM, M.; RUDNAI, P.; KÖZÉPESY, S.; DAVIDSON, F.; FISCHER, M. E.; JANASIK, B.; NAMORADO, S.; GURZAU, A. E.; JAJCAJ, M.; MAZEJ, D.; TRATNIK, D. J. S.; LARSSON, K.; LEHMANN, A.; CRETTAZ, P.; LAVRANOSAND, G.; POSADA, M. Fish consumption patterns and hair mercury levels in children and their mothers in 17 EU countries. Environmental Research, v. 141, p. 58-68, 2015.

[14] MALM, O.; DÓREA, J. G.; BARBOSA, A. C.; PINTO, F. N.; WELHE, P. Sequential hair mercury in mothers and children from a traditional riverine population of the Rio Tapajós, Amazonia. Environmental Research, n. 110, v. 7, p.705-709 (2010).

[15] ROCHA, A.V.; CARDOSO, B. R.; COMINETTI, C.; BUENO, R. B.; DE BORTOLI, M. C.; FARIAS, L. A.; FÁVARO, D. I. T.; CAMARGO, L. M. A; COZZOLINO, S. M. F. Selenium status and hair mercury levels in riverine children from Rondônia, Amazonia. Nutrition, v. 30, p.1318-1323, 2014.

[16] MONTUORI, P.; JOVER, E.; DIÉZ, S.; RIBAS-FITÓ, N.; SUNYER, J.; TRIASSI, M.; BAYONA, J. M. Mercury speciation in the hair of pre-school children living near a chlor-alkali plant. Science of the Total Environment, v. 369, p.51-58, 2006. 